\title{
Pyle metaphyseal dysplasia in an African child: Case report and review of the literature
}

\author{
A Wonkam, ${ }^{1} \mathrm{MD}$, DMedSc, $\mathrm{PhD}$; N Makubalo, ${ }^{1} \mathrm{MB} \mathrm{ChB} ; \mathrm{T}$ Roberts, ${ }^{2,3} \mathrm{BChD}, \mathrm{MChD}, \mathrm{PhD}$ candidate; \\ M Chetty, ${ }^{2,3} \mathrm{BChD}, \mathrm{MChD}, \mathrm{PhD}$ candidate \\ ${ }^{1}$ Division of Human Genetics, Department of Medicine, Faculty of Health Sciences University of Cape Town, South Africa \\ ${ }^{2}$ Division of Human Genetics, Department of Pathology, Faculty of Health Sciences, University of Cape Town, South Africa \\ ${ }^{3}$ Faculty of Dentistry, University of the Western Cape, Bellville, South Africa
}

Corresponding author: A Wonkam (ambroise.wonkam@uct.ac.za)

\begin{abstract}
Pyle disease (OMIM 265900), also known as metaphyseal dysplasia, is a rare autosomal recessive disorder with no known gene mutation. We report a case of Pyle disease in a 7-year-old African boy of mixed ancestry who presented with finger and wrist fractures following minor trauma. The radiological findings revealed abnormally broad metaphyses of the tubular bones, known as Erlenmeyer-flask bone deformity, and mild cranial sclerosis, both hallmarks of the condition. We report the first case in a patient with African ancestry, which could help in the gene discovery of this rare autosomal recessive skeletal dysplasia with unknown mutations.
\end{abstract}

S Afr Med J 2016;106(6):S110-S113. DOI:10.7196/SAMJ.2016.v106i6.11011

Pyle disease is an extremely rare autosomal recessive disorder of skeletal dysplasia, with fewer than 30 cases reported worldwide. The first case was reported by Pyle ${ }^{[1,2]}$ in 1931, as a case of unusual bone development. Pyle disease is a skeletal dysplasia in which a defect in metaphyseal remodelling leads to distinguishing bone findings of grossly widened metaphyses of long bones, giving Erlenmeyerflask bone shape. The clinical features are usually mild genu valgum, dental caries and malocclusion, and spinal misalignment. There is usually no facial dysmorphism or nerve compression, and the intelligence is normal.

Previously in South Africa (SA), four cases of Pyle disease were reported in patients of European ancestry, with familial history of consanguinity in two cases ${ }^{[3]}$ revealing the autosomal recessive mode of transmission. ${ }^{[4]}$

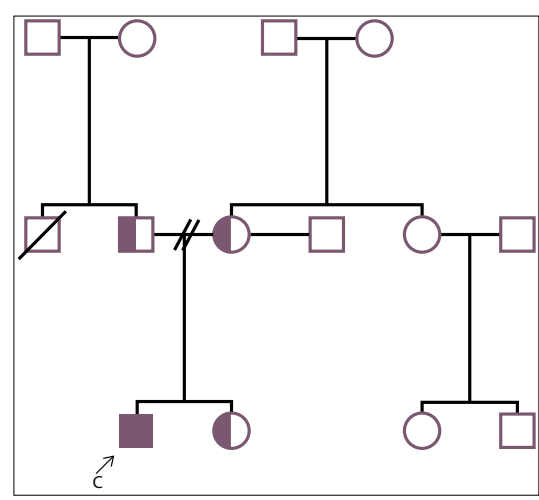

Fig. 1. The pedigree. The patient (indicated with the arrow) was a member of a family of two siblings; his 16-year-old sister was healthy as well as the two parents, and no other relevant family history was reported.
To date, no cases have been reported in patients with African ancestry. We report a case of Pyle disease in a 7-yearold African boy of mixed ancestry who presented with finger and wrist fractures following minor trauma, and review the literature with particular consideration of clinical and radiological findings of reported cases.
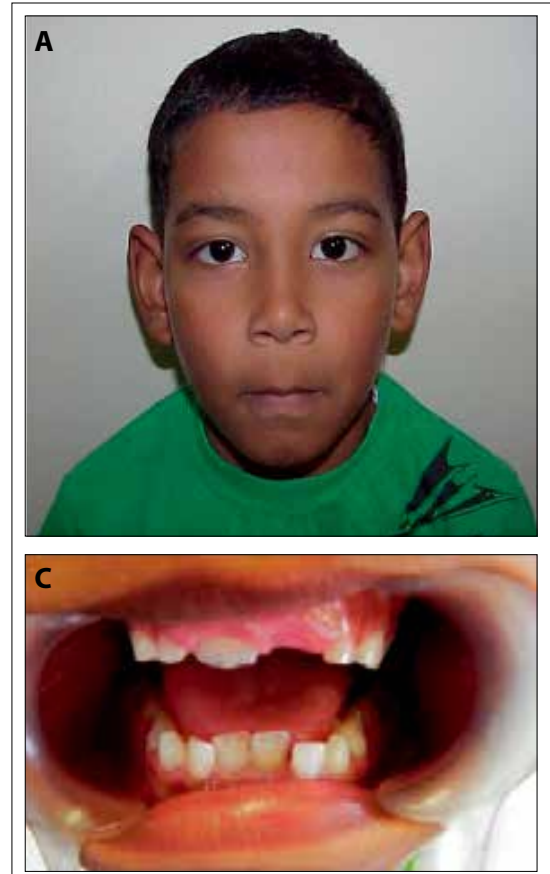

\section{Case report}

A 7-year-old boy presented with fractures of wrist and finger following minor trauma. He was referred for assessment after radiological findings of Erlenmeyer-flask bone deformity. The patient was a member of a family of two siblings; his 16-year-old sister was healthy, as well as the two parents, and no other relevant family history was reported (Fig. 1). There
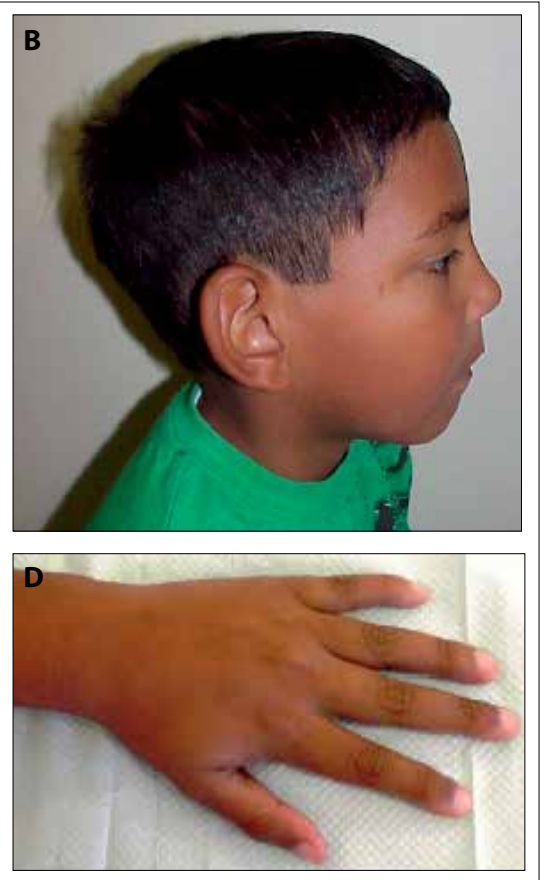

Fig. 2. Facial, dental and hand clinical phenotypes. $(A, B)$ The patient presented with mild dysmorphic features: prominent ears, flat frontal area and mandibular prognathism. Oral examination showed the presence of first permanent molars plus central mandibular and maxillary incisors. (C) The remaining teeth were all deciduous. Oral hygiene was good and apart from occasional caries, there were no notable abnormalities. (D) The hands appeared to have normal morphology. 
was no history of consanguinity; however, third-degree relatives came from the same geographical area in the Western Cape. Since the family was of mixed ancestry, we further intensively detailed family genealogy. Surname history did not reveal any relationship with previously reported SA cases $^{[3,4]}$ in patients of Afrikaner origin, also from the Western Cape Province.

On clinical examination, height, weight and head circumference were average for age. Developmental milestones and intelligence were normal. Facially, he presented with mild dysmorphic features: prominent ears, flat frontal area and mandibular prognathism (Fig. 2A, B). Oral examination showed the presence of first permanent molars plus central mandibular and maxillary incisors. No other permanent teeth were visible. The remaining teeth were all deciduous. Oral hygiene was good, and apart from occasional caries there were no notable abnormalities (Fig. 2C). The hands were both without anomalies (Fig. 2D). Skeletal system showed mild genu valgum and widened thickened metaphysis of the long bones, particularly the femora and tibiae. There was no scoliosis, no

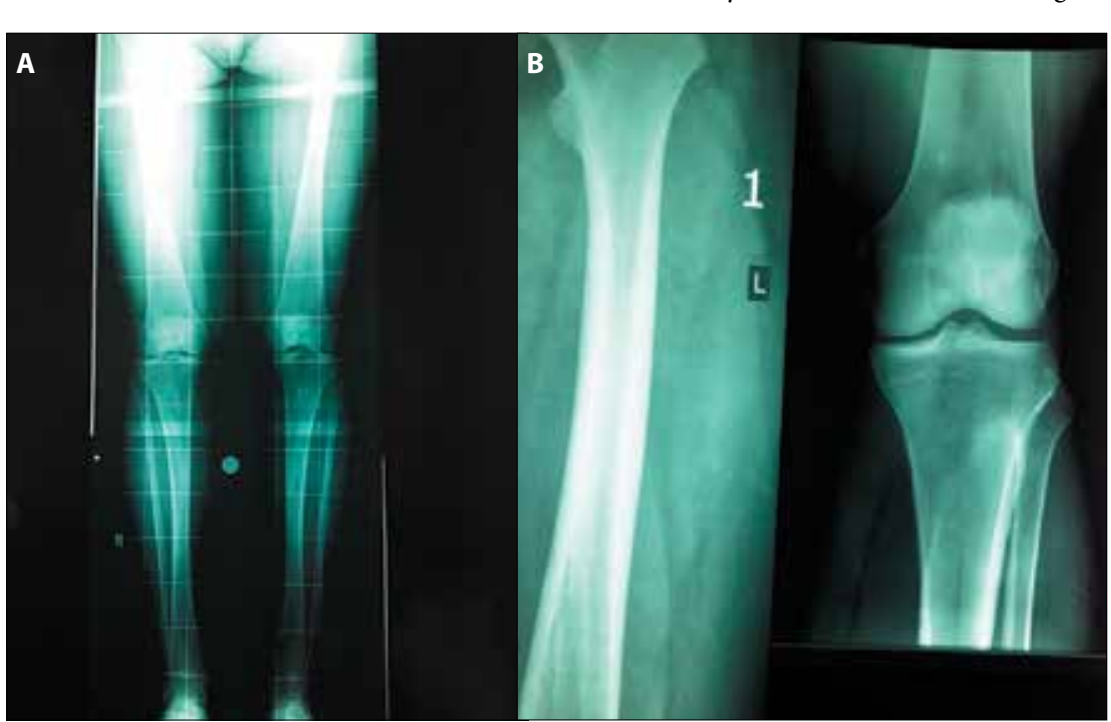

Fig. 4. Radiographic images of parents. (A) A mild metaphyseal expansion of long bones could be described on the mother's radiography, suggesting heterozygocity. (B) Father's long-bone radiography was normal.
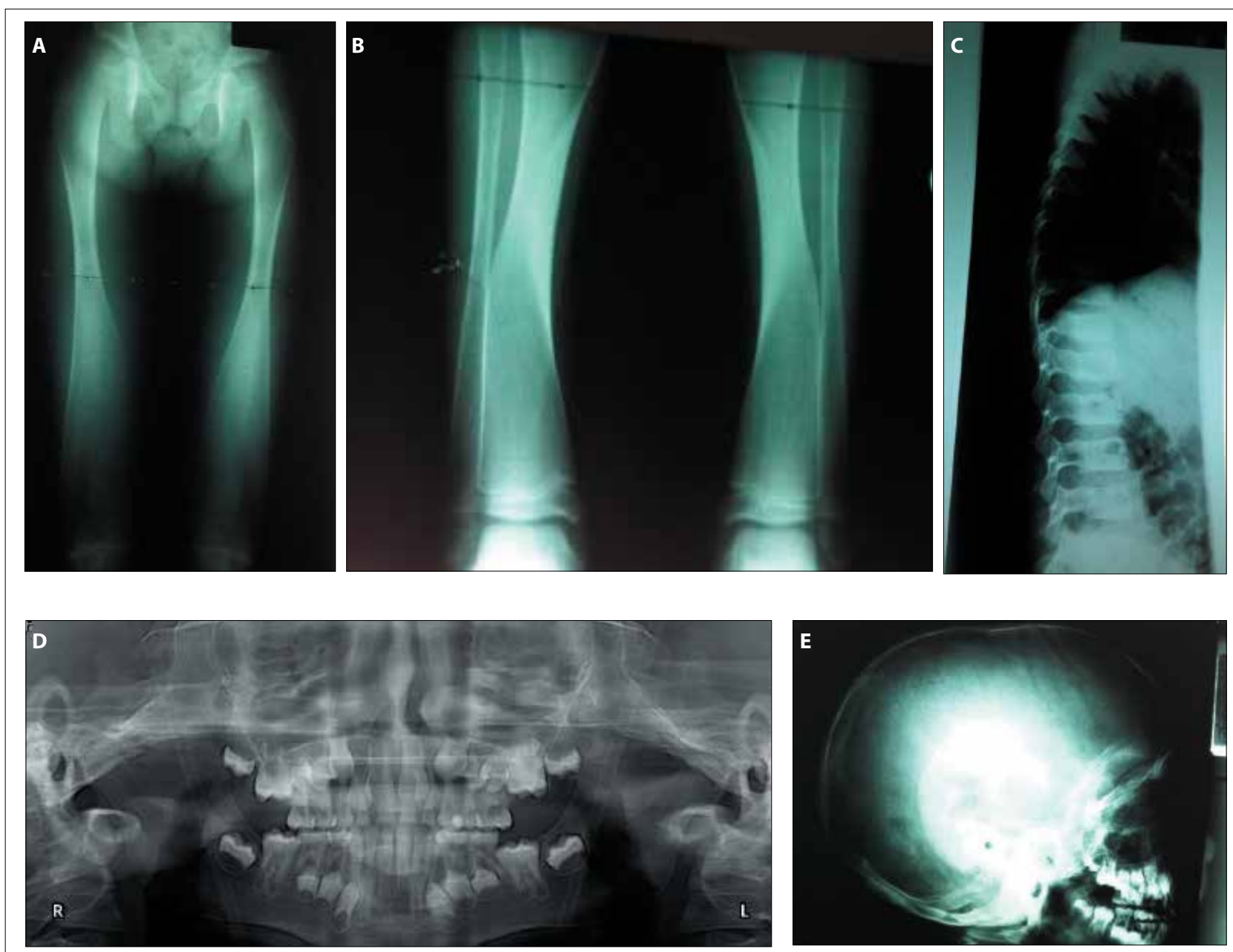

Fig. 3. Skeletal survey revealed: $(A, B)$ the long bones showing gross metaphyseal expansion of upper third of both femora and tibiae and the Erlenmeyer deformity of the long bones; $(C)$ the spine showed a generalised platyspondyly; (D) there were no notable maxillofacial or dental deformities; and $(E)$ the skull showed Wormian bones, thin calvarium and bossed forehead. 
Table 1. Patient description and comparative review of the literature

\begin{tabular}{|c|c|c|c|c|c|}
\hline Countries & Presentation & Fracture & Dysmorphism & Radiological features & Reference \\
\hline South Africa & Minor trauma & + & + & $\begin{array}{l}\text { Skull: thin cranial bones, bossing forehead, Wormian bones } \\
\text { Thorax: widened clavicles and ribs medially } \\
\text { Spine: flat vertebral bodies (platyspondyly) } \\
\text { Long bones: gross metaphyseal expansion of upper two-thirds of } \\
\text { femora and tibia } \\
\text { Hands: undemodelling of metacarpals }\end{array}$ & $\begin{array}{l}\text { The present } \\
\text { case }\end{array}$ \\
\hline South Africa & Wrist injury & + & - & $\begin{array}{l}\text { Skull: patchy sclerosis was present in the calvarium, parasinuses and } \\
\text { mastoid air cells showed partial or complete pneumatisation } \\
\text { Thorax: clavicles flared medially, ribs widened to a lesser degree } \\
\text { Spine: mild dorsal scoliosis } \\
\text { Long bones: EFD of long bones, undertubulation of humerus in its } \\
\text { proximal two-thirds, undertubulation of radius and ulna in the distal two- } \\
\text { thirds, metacarpals undermodelled distally, healed old fractures }\end{array}$ & 7 \\
\hline South Africa & $\begin{array}{l}\text { Investigated } \\
\text { following a } \\
\text { proband }\end{array}$ & - & - & $\begin{array}{l}\text { Skull: patchy sclerosis of calvarium, poor pneumatisation of mastoid } \\
\text { air cells and paranasal sinuses } \\
\text { Chest: clavicles markedly flared medially } \\
\text { Pelvis: widening of ischio-pubic rami } \\
\text { Long bones: undertubulation of radius and ulna in the distal } \\
\text { two-thirds } \\
\text { Hands: metacarcapals } 2 \text { - } 5 \text { undermodelled distally }\end{array}$ & 7 \\
\hline South Africa & $\begin{array}{l}\text { Lower back } \\
\text { pain }\end{array}$ & - & - & $\begin{array}{l}\text { Skull: patchy sclerosis was present in the calvarium, prognathism was } \\
\text { present, paranasal sinuses and mastoid air cells showed partial or } \\
\text { complete pneumatisation } \\
\text { Thorax: flaring of the clavicle more marked medially } \\
\text { Spine: lumbosacral spondylosisthesis and mild platypondyly in the } \\
\text { dorsal spine } \\
\text { Long bones: undertubulation of radius and ulna in the distal two- } \\
\text { thirds, tibia show predominantly proximal flaring with lateral } \\
\text { S-shaped bowing }\end{array}$ & 7 \\
\hline India & Trivial trauma & + & - & $\begin{array}{l}\text { Skull: normal } \\
\text { Chest: normal } \\
\text { Spine: platyspondyly of dorso lumbar spine } \\
\text { Long bone: EFD of long bones, multiple growth arrest lines, diffuse } \\
\text { osteopenia and bowing of bilateral tibiae }\end{array}$ & 8 \\
\hline India & $\begin{array}{l}\text { Incidental } \\
\text { finding in } \\
\text { routine dental } \\
\text { patient }\end{array}$ & + & - & $\begin{array}{l}\text { Skull: mild basal sclerosis, non-pneumatisation of frontal sinus and } \\
\text { partial obliteration of maxillary sinuses } \\
\text { Chest: widening of the medial end of both clavicles, ribs also } \\
\text { appeared widened with loss of corticomedullary differentiation, and } \\
\text { thinning cortex } \\
\text { Long bone: EFD of metaphyses of both femora, diapyses appeared } \\
\text { spaced, tibia, fibula and humerus also showed remodelling defect with } \\
\text { EFD, fibula appeared widened with ground-glass opacity }\end{array}$ & 9 \\
\hline Italy & Back pain & + & No comment & $\begin{array}{l}\text { Spine: platyspondyly of spine and lumbar osteoporosis with } \\
\text { pathological fractures } \\
\text { Long bones: EFD of long bones }\end{array}$ & 9 \\
\hline Ireland & $\begin{array}{l}\text { Pain and } \\
\text { deformity of leg }\end{array}$ & + & - & $\begin{array}{l}\text { Skull: thickening and increased density in the base and facial region. } \\
\text { Absent pneumatisation of maxillary, frontal and sphenoid sinusesand } \\
\text { sclerosis of the petrous ridges with thickening of the posterior } \\
\text { clinoids. Mandible showed lack of modelling with some prognathism } \\
\text { Thorax: no comment } \\
\text { Spine: many lumbar vertebrae have collapsed with loss of normal } \\
\text { trabeculation, similar changes in the dorsal spine } \\
\text { Pelvis: showed protrusion acetabula and widening of the pubic rami } \\
\text { Long bone: marked thinning of cortex at the metaphysis and a } \\
\text { relative absence of trabeculation giving a ground- glass appearance. } \\
\text { Fractures of right tibia and fibula } \\
\text { Hands: tubula metacarpals with almost total absence of modelling. } \\
\text { Similar changes affect bones of forearm and humerus. A healed } \\
\text { fracture of the left radius }\end{array}$ & 5 \\
\hline
\end{tabular}


investigations revealed normal chemistry including calcium and liver functions and normal haematological parameters. Karyotype revealed normal $46 \mathrm{XY}$ chromosomal constitution. Skeletal survey (Fig. 3) revealed metaphyseal expansion of the upper third of both femora and tibiae, and the Erlenmeyer deformity of the long bones (Figs 3A, B); the cortex of long bones was very thin with normal epiphyses (Figs 3A, B); the spine revealed generalised platyspondyly (Fig. 3C); there were no notable maxillofacial or dental deformities (Fig 3D) and the skull showed Wormian bones, thin calvarium, mild cranial sclerosis and bossed forehead (Fig. 3E). A mild metaphyseal expansion of long bones could be described on the mother's radiography (Fig. 4A) as well as that of the sister. Father's radiography was normal (Fig. 4B).

\section{Discussion}

Pyle disease is a rare autosomal recessive skeletal dysplasia without a known causative gene. There are about 20 reported cases worldwide; a few whose full report it was possible to obtain are presented here (Table 1). Pyle disease is characterised by Erlenmeyer-flask deformity (EFD), which results from defective bone modelling at the metadiaphyseal region leading to straight, uncurved dimetaphyseal borders and cortical thinning, giving the appearance of EFD.

The differential diagnosis for EFD includes other craniotubular bone dysplasias such as craniometaphyseal dysplasia, craniodiaphyseal dysplasia, Nieman-Pick disease, Gaucher disease and thalassaemia. Pyle disease is often confused with craniometaphyseal dysplasia. ${ }^{[5]}$ In 1970, Gorlin et al. ${ }^{[6]}$ described craniometaphyseal dysplasia as a distinct entity separate from Pyle disease. Pyle disease has gross widening of metaphyses with mild cranial sclerosis in contrast with other craniometaphyseal dysplasias, which have severe craniofacial or greater cranial sclerosis with mild metaphyseal changes.Despite the remarkable radiological features of Pyle disease, the phenotypic features are usually mild. ${ }^{[7]}$ In the few reported cases of Pyle disease, including the present case, no or mild craniofacial dysmorphism or cranial nerve compression has been involved (Table 1).

Although the oral findings of the disease are not well documented, several of the features that prevailed in our patient have been previously reported..$^{[8]}$ The odontostomatological problems found in patients with Pyle disease are less important than their orthopaedic disorders, but they can stimulate the interest of the clinician to further investigate the possibility of the presence of a bone dysplasia. ${ }^{[8-10]}$ Generally, craniofacial bones are only mildly affected. Often, an orthopantomographic radiograph is necessary to diagnose maxillofacial and dental deformities associated with this disorder. In 1967, Ross and Altman ${ }^{[11]}$ reviewed the literature and cited previous literature as it related to Pyle's work. They summarised the clinical and radiographic findings, including maxillofacial and dental manifestations. These included prolonged retention of deciduous teeth, delayed eruption of permanent teeth, and numerous dental fillings and/or other evidence of dental caries. In 2007, Narayananan et al. ${ }^{\left[{ }^{9]}\right.}$ reported a case of an incidental finding of Pyle disease in a routine dental patient with missing permanent teeth and retained deciduous teeth. As patients enter their early teenage years, several require orthodontic intervention due to a malocclusion that may develop as a result of delayed eruption and loss of teeth due to caries. ${ }^{[8,9]}$ Comparing radiological features from other cases in the literature, there was no significant difference in dental and other skeletal features (Table 1).

In 1978, Raad et al. ${ }^{[4]}$ reported minor degrees of undermodelling of the distal regions of femora of obligatory and potential heterozygotes in their patient's family. Our patient's sister and mother had mild radiological features which could be subclinical expression in the carrier gene. The father of the index patient had no obvious radiological features (Fig. 4). Other cases of familial Pyle disease have been reported in France, ${ }^{[12,13]}$ Italy, $^{[14,15]}$ Portugal ${ }^{[16]}$ and Australia, ${ }^{[17]}$ but surprisingly the gene involved in this condition is not yet reported. ${ }^{[18]}$

\section{Conclusion}

We have reported the first case of Pyle disease in patients of African ancestry. For this rare autosomal recessive skeletal dysplasia with no known gene(s), this present case, in addition to a few others reported worldwide, may offer an opportunity to explore the whole genome sequences in order to identify the causative mutation. Any gene discovery will add to better knowledge of bone remodelling and increase insight into therapies for other bone conditions such as osteoporosis.

Acknowledgement. Material patterned to the dental aspect of Pyle disease and presented in the article has been featured in the $\mathrm{PhD}$ thesis submitted to the University of Cape Town by Dr M Chetty.

\section{References}

1. Faden MA, Krakow D, Ezgu F, Rimoin DL, Lachman RS. The Erlennmeyer flask deformity in the skeletal

dysplasias. Am J Med Genet A 2009;149A(6):1134-1345. DOI:10.1002/ajmg.a.32253
2. Pyle E. A case of unusual bone development. J Bone Joint Surg Am 1931;13: 874-876. 3. Beighton P. Pyle disease (metaphyseal dysplasia). J Med Genet 1987;24(6):321-324. DOI:10.1136/

jmg.24.6.321.

MS, Beighton P. Autosomal recessive inheritance of metaphyseal dysplasia (Pyle disease). Clin Genet 1978;14(5):251-256. DOI:10.1111/j.1399-0004.1978.tb02142.x

5. Small PG, Wallis JJ. Pyle's disease or craniometaphyseal dysplasia (tarda). Br J Radiol 1970;43(515):811813. DOI:10.1259/0007-1285-43-515-81

6. Gorlin RJ, Koszalka MF, Spranger J. Pyle's disease (familial metaphyseal dysplasia). A presentation of two cases and argument for its separation from craniometaphyseal dysplasia. J Bone Joint Surg Am 1970;52(2):347-354

7. Heselson NG, Raad MS, Hamersma H, Cremin BJ, Beighton P. The radiological manifestations of metaphyseal dysplasia (Pyle disease). Br J Radiol 1979;52(618):431-440. DOI:10.1259/0007-1285-52618-431

8. Gupta N, Kabra M, Das CJ, Gupta AK. Pyle metaphyseal dysplasia. Indian Pediatr 2008;45(4):323-325. 9. Narayananan VS, Ashok L, Mamatha GP, Rajeshwari A, Prasad SS. Pyle’s disease: an incidental findin in a routine dental patient. Dentomaxillofac Radiol 2006:35(1):50-54.DOI:10.1259/dmfr/44987850

10. Turra S, Gigante C, Pavanini G, Bardi C. Spinal involvement in Pyle's disease. Pedatr Radiol 2000;30(1):25-27. DOI:10.1007/s002470050006

1. Ross MW, Altman DH. Familial metaphyseal dysplasia. Review of the clinical and radiologic feature of Pyles disease. Clin Pediatr (Phila) 1967;6(3):143-149. DOI:10.1177/000992286700600309

12. Borget C, Le Bail-Darne JL, Bardin T, Bard M, Kuntz D. Pyle’s disease. Review of the literature apropos of a case. Rev Rhum Mal Osteoartic 1991;58(4):291-294.

13. Verger P, Guichard, Puyjalon. [Pyle's disease or familial metaphysial dysplasia (apropos of a new case)]. Pediatrie 1960;15:27-34.

14. Ferrari D, Magnani M, Donzelli O. Pyle's disease. A description of two clinical cases and a review of the literature. Chir Organi Mov 2005;90(3):303-307.

15. Gambardella A, Ciccarelli R, Pepe A, Mosca A. [Familial metaphyseal dysplasia (Pyle’s disease) versu craniometaphyseal dysplasia. Presentation of a case]. Radiol Med 1990;80(3):360-363.

6. Oppenheimer C, Oliveira BC, Sogabe M, Sanvito W. [Pyle’s syndrome: report of a case]. Arq Neuropsiquiatr 1996;54(1):120-123.

17. Vohra V. Pyle's disease-familial metaphyseal dysplasia - a case report. Australas Radiol 1987;31(1):7578. DOI:10.1111/j.1440-1673.1987.tb01788.x

18. Faden MA, Krakow D, Ezgu F, Rimoin DL, Lachman RS. The Erlenmeyer flask bone deformity in the skeletal dysplasias. Am J Med Genet 2009;149A(6):1334-1345. DOI:10.1002/ajmg.a.32253 